\title{
Economic Reductionism, Formulaic Responses and Pushing Allies Away? A Response to Some Comments on Marxism and Educational Theory: Origins and Issues
}

Kevin Murray and Daniel P. Liston are of the opinion that my book, Marxism and Educational Theory: Origins and Issues (METOI), "offers both a helpful primer on Marxist educational theory as well as sophisticated analyses of twentieth-century 'advances' on Marxist educational framings."2 Michael Apple, on the other hand, states:

Even though [METOI] argues at one or two junctures against an economically deterministic version of Marxism, its proposed alternative is still largely a restored economistic Marxism. In a number of ways, it reads like something of a primer on this limited version of Marxism. ${ }^{3}$

Apple believes that, because of its "economic reductionism" and "formulaic responses that obliterate complexities, intersecting power relations and oppressions", the book unfortunately pushes possible allies away. ${ }^{4}$

Given that Apple makes a large number of critical comments about METOI, in the spirit of comradely debate, I will focus my response on Apple's exegesis. Cautioning against "using class as the only element that should be privileged in critical analysis"5 (which I don't), Michael Apple, who believes in "the relatively autonomous politics involving race and gender", makes the case that my "economistic assumptions" are revealed when I do "not go far enough" in allowing "the interconnections of class and "race"" to challenge these assumptions. ${ }^{7}$ Apple gives the example of slavery, correctly noting that the "enslavement and trade in black persons" is one of "the most significant roots of capital accumulation during the growth of capitalism as a global economic system." ${ }^{8}$ His implication is that I make no mention of slavery. This is factually inaccurate in that I do discuss the slave trade in $M E T O I^{9}$ when I describe how modern racist ideology emerged with and from the Atlantic slave trade. Following Critical Race Theorist Paul Warmington, I describe too how racialization served to

\footnotetext{
${ }^{1}$ Mike Cole, Marxism and Educational Theory: Origins and Issues (London and New York: Routledge, 2008).

${ }^{2}$ Murray and Liston, 10

${ }^{3}$ Apple, 21

${ }^{4}$ Apple, 5

${ }^{5}$ Apple, 8

${ }^{6}$ Apple, 4

${ }^{7}$ Apple, 7

${ }^{8}$ Apple, 7

${ }^{9}$ Cole, Marxism and Educational Theory, 106-7
} 
justify "brutal, servile productions systems." "I I also quote Genovese and Genovese ${ }^{11}$ who argue that the rising capitalist class "required a violent racism not merely as an ideological rationale but as a psychological imperative." 12 To be fair to Apple, a drawback of being asked to review a single book of any given author is that, in not contextualising that one work, the assessment of the author's overall theoretical orientation can be skewed. Thus, elsewhere I devote some six and a half pages to African enslavement on American soil, where I quote Marx and Engels famous dictum that slavery was as crucial to English capitalism as the growth of machinery. ${ }^{13}$

While Apple acknowledges that I take "race" seriously both in METOI and elsewhere, he still makes the claim that my work is "more than a little reductive."14 This is despite the fact that I devote an Appendix to METOI critiquing some Marxist sociologists who stress the need to use Marxist terminology rather than the concept of racism. I refer to discussions at a conference I attended at Glasgow in 2006, in the Department of Sociology at the University of Glasgow, where the influential Marxist sociologist, Robert Miles was a (full) professor in the 1990s. ${ }^{15}$ Miles' arguments ${ }^{16}$ against inflating the concept of racism to include actions and processes as well as discourses, and his contention that "racism" should be used to refer exclusively to an ideological phenomenon, and not to exclusionary practices had a fervent following in the Department at the time. As I put it, while I understand these Marxist sociologists' desire to retain a Marxist analysis and not to reify racism, and while I believe they are right to be wary of any tendency to just call everything "racist" and thereby to foreclose an analysis of various practices in different historical periods of capitalist

\footnotetext{
${ }^{10}$ Cole, Marxism and Educational Theory, 107.

${ }^{11}$ Elizabeth Fox-Genovese and Eugene D Genovese, The Fruits of Merchant Capital: Slavery and Bourgeois Property in the Rise and Expansion of Capitalism (Oxford: Oxford University Press, 1983) cited in Peter Fryer, Black People in the British Empire: An Introduction (London: Pluto Press, 1988), 63.

${ }^{12}$ Genovese and Genovese, The Fruits of Merchant Capital: Slavery and Bourgeois Property in the Rise and Expansion of Capitalism, cited in Peter Fryer, Black People in the British Empire: An Introduction, 63, and in Cole, Marxism and Educational Theory, 107.

${ }^{13}$ Karl Marx and Friedrich Engels, "Letters: Marx to P. V. Annenkov in Paris," in Karl Marx and Friedrich Engels, Selected Works in One Volume (London: Lawrence and Wishart, 1846 [1977]), 665.
}

\footnotetext{
${ }^{14}$ Apple, 22

${ }^{15}$ Cole, Marxism and Educational Theory, 140-1

${ }^{16}$ e.g. Robert Miles Racism (London: Routledge, 1989), 78.
} 
development (a criticism I subsequently levelled at some Critical Race Theorists) ${ }^{17}$ this "is not to say that all individual or institutional instances of racism and ... racialization are reducible to the economy." 18

Apple also claims that I stereotype "some of the best of critical race theory." 19 While I acknowledge that my consideration of Critical Race Theory (CRT) in METOI is brief, I did alert readers of METOI to "further developments of my Marxist critique of CRT" in a forthcoming journal article. ${ }^{20}$ Furthermore, I expanded my analysis considerably in my book, Critical Race Theory and Education: a Marxist Response. ${ }^{21}$ In that book, I tried to be as comprehensive of the CRT movement as I could, and included chapters on its origins and varieties and on its strengths. Indeed, in order to make sure I was giving fair treatment and not stereotyping or misrepresenting CRT, I took advice and comments throughout the writing of the book from a large number of leading Critical Race Theorists including the late Derrick Bell, Adrienne Dixson, Gloria Ladson-Billings, Charles Mills, and John Preston. The observation on the back cover of that book by one of the founders of the CRT movement, Richard Delgado, who offered extensive comments during its gestation, does not concur with the stereotyping of CRT. He wrote: "Any movement would be fortunate to have the meticulous but wide-ranging criticism that Cole offers".

Apple favours intersectionality, and while this is not a term I identify with myself, I have been writing about "race", as he acknowledges, for many years. I have also published over a number of years edited collections that consider gender, sexuality, and disability in addition to "race" and class. At the time of the publication of METOI, my edited collection, Education

\footnotetext{
${ }^{17}$ Mike Cole, Critical Race Theory and Education: a Marxist Response (New York and London: Palgrave Macmillan, 2009), Chapter 2.

${ }^{18}$ Cole, Marxism and Educational Theory, 141, emphasis added.

${ }^{19}$ Apple, 22

${ }^{20}$ Cole, Marxism and Educational Theory, 153. The article which I described as Cole, 2008 was actually published the following year: Mike Cole, 'Critical Race Theory Comes to the UK: a Marxist Response', Ethnicities 9 (2), 2009.
}

${ }^{21}$ Cole, Critical Race Theory and Education. 
Equality and Human Rights: Issues of Gender, 'Race', Sexuality, Disability and Social Class was in its second edition (now in its third). ${ }^{22}$

Apple refers to "base/superstructure theories that have been criticized for decades within Marxist theories (a literature and robust series of debates that Cole for example either ignores or dismisses)". ${ }^{23}$ I do not know the basis for this assertion. I have always shied away from formulaic "base determines superstructure" analyses. Indeed, I myself have been part of the literature that he refers to. For example in 1988, I edited the book, Bowles and Gintis Revisited,$^{24}$ as a retrospective on Bowles and Gintis's classic volume, Schooling in Capitalist America. ${ }^{25}$ There I deliberately invited contributions from authors who would question deterministic base/superstructure theories, who would reject "class only" models and would also consider "race" and gender. In that text Apple argued for a "parallelist position" with respect to class, gender and "race." ${ }^{26}$ As I wrote in that volume, when referring to Gintis' and Bowles' subsequent rejection of a simplistic base/superstructure model ${ }^{27}$ that they espoused in Schooling and Capitalist America, ${ }^{28}$ "it is pertinent to ask why they ever had such a model in the first place. ${ }^{29}$ I went on to quote Althusser who argued that economism is a mere inversion of Hegel. As Althusser stated, while "for Hegel, the politico-ideological was the essence of the economic", a reading of Marx which reduces the dialectic of history to the "dialectic generating the successive modes of production" is to simply make "the economic

${ }^{22}$ Mike Cole, ed., Education, Equality and Human Rights: Issues of Gender, "Race", Sexuality, Disability and Social Class, $2^{\text {nd }}$ Edition (London and New York: Routledge, 2006). ${ }^{23}$ Apple, 9.

${ }^{24}$ Mike Cole, ed., Bowles and Gintis Revisited: Correspondence and Contradiction in Educational Theory (Barcombe: The Falmer Press, 1988).

${ }^{25}$ Herbert Gintis and Samuel Bowles, Schooling in Capitalist America: Educational Reform and the Contradictions of Economic Life (London: Routledge and Keegan Paul, 1976).

${ }^{26}$ Michael Apple "Facing the Complexity of Power: For a Parallelist Position in Critical Educational Studies," in Bowles and Gintis Revisited, ed. Mike Cole, 1988).

${ }^{27}$ Herbert Gintis and Samuel Bowles "Contradiction and Reproduction in Educational Theory" in Schooling, Ideology and the Curriculum, eds. Len Barton, Roland Meighan and Stephen A Walker (Lewes: The Falmer Press. This chapter is reproduced as Chapter 2 of Bowles and Gintis Revisited, ed. Mike Cole, 1988.

${ }^{28}$ Herbert Gintis and Samuel Bowles, Schooling in Capitalist America (London: Routledge and Keegan Paul, 1976).

${ }^{29}$ Mike Cole, "Contradictions in the Educational Theory of Gintis and Bowles", Bowles and Gintis Revisited, ed. Mike Cole, 1988, 36 
... the essence of the politico-ideological." ${ }^{, 30}$ The rest of my chapter is primarily concerned with an analysis of the importance of gender and "race," and in an earlier chapter in the book I referred to Bowles and Gintis's 'relative neglect of gender and "race". 31

Related to my belief in the importance of gender and "race", I have also consistently distanced myself from simplistic twentieth century models of "socialism" that prefigure the white male working class and ignore issues of exploitation and oppression directed at women, people of color, people with disabilities and people with different non-exploitative sexualities. Indeed, in a number of works ${ }^{32}$, but also in the Afterword of METOI, I identify closely with twenty-first century socialism in Venezuela which differs in many ways from Stalinism, in particular in the central involvement of women of color. ${ }^{33}$

The intention of METOI was to investigate the origins of Marxist theory and to look at some of the responses to this theory, including postmodern and poststructuralist feminism and Critical Race Theory. In so doing, I do not accept that the resulting analyses were economic reductionist.

I do accept, however, that there is not a lot of attention devoted to actual classroom strategies, something noted by both Murray and Liston and Apple. Murray and Liston may be right when they say that my analysis "is so abstract that we can, at times, lose the affective and programmatic educational elements." ${ }^{34}$ Similarly, Apple remarks: "chapters end with an obligatory 'implications for education' section, one that is usually one or two pages at most." He continues: "these are no more than suggestions such as 'Students need to be aware of imperialism"" and "they do not help us go beyond his answer that schools can't do much of anything that has serious implications for transformation". ${ }^{35}$ I can only comment that this

${ }^{30}$ Louis Althusser, For Marx (London: Verso, 1979, p. 108), cited in Mike Cole, "Contradictions in the Educational Theory of Gintis and Bowles", 1988, 36.

${ }^{31}$ Mike Cole, "Correspondence Theory in Education: Impact, Critique and Re-evaluation" Bowles and Gintis Revisited, ed. Mike Cole, 1988, 10.

${ }^{32}$ Most recently, Sara C. Motta and Mike Cole, Constructing Twenty-First Century Socialism in Latin America: The Role of Radical Education (New York: Palgrave Macmillan, 2014)

${ }^{33}$ See Sara C. Motta and Mike Cole "Opinion: The giant school's emancipatory lessons" Times Higher Education 13 January 2011 http://www.timeshighereducation.co.uk/news/opinion-the-giant-schools-emancipatorylessons/414858.article

${ }^{34}$ Murray and Liston, 24

${ }^{35}$ Apple, 22-23. 
was the result of a felt need to make at least some practical suggestions in a book that is fundamentally "theoretical". While I believe firmly in praxis - the authentic union of theory and practice - there is a need for publications that attempt to promote theoretical as well as practical concerns. Over the years, I have published a large number of books and articles which give precedence to practice.

With respect to pushing possible allies away, this, of course, has never been my intention, as Apple recognizes. In METOI, I make it clear that I do not see post-structuralists and postmodernists as allies in the struggle against capitalism. Murray and Liston have developed this further in their review of METOI. They refer to critique generated by Marxist feminist Teresa Ebert. ${ }^{36}$ Ebert argues that, despite the stated ends of postmodernism, these theories have tended to serve the interests of dominant groups. She maintains that the transformation of political struggle into identity politics benefits what she calls "the managerial class."37 Ebert suggests that postmodernist theory and practice "might make the upper-middle class intellectual feel empowered and enabled but will leave the existing social practices intact." 38 As Murray and Liston conclude,

We share Ebert's suspicion that postmodernist theory, as far as it fails to make significant connections to capitalist economic processes, obscures that middle and upper middle class individuals often constitute the very managerial class that stands to benefit from the continued existence of capitalism. These theories might well serve as ideological mystification of the objective class positioning of intellectuals and their relations to the working class and working poor whose labor sustains their privileged positions. $^{39}$

I have not been so dismissive of Critical Race Theorists, with respect to anti-capitalist praxis. Indeed in METOI, when referring to Delgado's advocacy of materialist as opposed to discourse-focused CRT, I wrote that, for Marxists "these are promising developments and point towards a possible alignment between CRT and Marxism." 40 I repeated my request for an alliance at the end of Critical Race Theory and Education when I stated:

I would like to appeal to Critical Race Theorists and Critical Legal Studies scholars to join me in productive antiracist dialogue in order to see if we can agree how to move theory and action (praxis) forward. ${ }^{41}$

\footnotetext{
${ }^{36}$ Teresa Ebert, “Rematerializing Feminism," Science and Society 69 no. 1 (2005): 33-55.

${ }^{37}$ Ebert, "Rematerializing Feminism," 38.

${ }^{38}$ Ebert, "Rematerializing Feminism," 37-38.

${ }^{39}$ Murray and Liston, ?

${ }^{40}$ Mike Cole, Marxism and Educational Theory, 116-7.

${ }^{41}$ Cole, Critical Race Theory and Education, 154.
} 
In hindsight these comments appear overly optimistic. I still believe, of course, that Critical Race Theorists can be allies in the fight against racism. However, their ambiguity about a future society makes it difficult for alignment in the struggle for socialism. As some leading Critical Race Theorists put it, CRT shares "an ethical commitment to human liberation" but Critical Race Theorists "often disagree among [themselves] over its specific direction". ${ }^{42}$ Often, their suggestions for the future are vague. Introducing their edited collection, Critical Race Theory in Education, Dixson and Rousseau write, for example, about "the struggle," "a vision of hope for the future," "social action toward liberation and the end of oppression," "the broader goal of ending all forms of oppression," and "the ultimate goal of CRT - social transformation." ${ }^{43}$ However, no indication is given of what they are struggling towards, what liberation means to them, or what is envisioned by social transformation and the end of all forms of oppression.

As recognized by the Left and many others, specific and concerted attention to the environment is required for the very survival of our planet and for the end of exploitation and oppression. So, my penultimate point is one of accuracy. Apple claims that one of the things that sets Blacker's The Falling Rate of Learning and the Neoliberal Endgame apart from the others he is reviewing, including mine, is "the attention it pays to environmental sustainability." 44 This assertion fails to mention that I devote a whole chapter of METOI to "Globalisation, neo-liberalism and environmental destruction."

I would like to conclude on a positive note. Murray and Liston and Apple both note the bleak structural fate apparent in Blacker's The Falling Rate of Learning. In that context, Apple invokes Gramsci's "pessimism of the intellect, optimism of the will." 46 There are signs that capitalism may be heading towards its second global crash in ten years, and for certain the

\footnotetext{
${ }^{42}$ Kimberle Crenshaw, Neil Gotanda, Gary Peller and Kendall Thomas "Introduction" to Critical Race Theory: The Key Writings that Formed the Movement, (New York: New Press, 1995), xiii

${ }^{43}$ Dixson and Rousseau, Critical Race Theory in Education, 3-7.

${ }^{44}$ Apple, 18.

${ }^{45}$ Mike Cole, Marxism and Educational Theory. 85-97.

${ }^{46}$ Apple, 17 
ruling class is interpellating ${ }^{47}$ the populace on the necessity (sic) of many more years of austerity/immiseration capitalism. I can only echo Murray and Liston's warning that, "It is time, we think, to be duly informed and act virtuously." ${ }^{48}$ For a number of years, there have been signs in Latin America of a fundamental reconsideration of the direction we might take. ${ }^{49}$ We could do worse than to look to the Global South for some possible models for development in the capitalist heartlands.

${ }^{47}$ Louis Althusser "Ideology and Ideological State Apparatuses", Althusser, L. Lenin and Philosophy and Other Essays (London: New Left Books), 1971.

${ }^{48}$ Murray and Liston, 30

${ }^{49}$ Motta and Cole, 2014; Sara C. Motta and Mike Cole (eds.) Education and Social Change in Latin America (New York and London: Palgrave Macmillan) 